OPEN ACCESS

Edited by:

Xavier Mayali,

Lawrence Livermore National

Laboratory, USA

Reviewed by:

Torsten Thomas,

The University of New South Wales,

Australia

Kim Thamatrakoln,

Rutgers University, USA

*Correspondence:

Rebecca J. Case

rcase@ualberta.ca

Specialty section: This article was submitted to

Aquatic Microbiology,

a section of the journal

Frontiers in Microbiology

Received: 18 January 2016

Accepted: 26 May 2016

Published: 13 June 2016

Citation:

Mayers TJ, Bramucci AR, Yakimovich KM and Case RJ (2016) A Bacterial

Pathogen Displaying Temperature-Enhanced Virulence of the Microalga Emiliania huxleyi.

Front. Microbiol. 7:892.

doi: 10.3389/fmicb.2016.00892

\section{A Bacterial Pathogen Displaying Temperature-Enhanced Virulence of the Microalga Emiliania huxleyi}

\author{
Teaghan J. Mayers, Anna R. Bramucci, Kurt M. Yakimovich and Rebecca J. Case*
}

Department of Biological Sciences, University of Alberta, Edmonton, AB, Canada

Emiliania huxleyi is a globally abundant microalga that plays a significant role in biogeochemical cycles. Over the next century, sea surface temperatures are predicted to increase drastically, which will likely have significant effects on the survival and ecology of $E$. huxleyi. In a warming ocean, this microalga may become increasingly vulnerable to pathogens, particularly those with temperature-dependent virulence. Ruegeria is a genus of Rhodobacteraceae whose population size tracks that of $E$. huxleyi throughout the alga's bloom-bust lifecycle. A representative of this genus, Ruegeria sp. R11, is known to cause bleaching disease in a red macroalga at elevated temperatures. To investigate if the pathogenicity of R11 extends to microalgae, it was co-cultured with several cell types of $E$. huxleyi near the alga's optimum $\left(18^{\circ} \mathrm{C}\right)$, and at an elevated temperature $\left(25^{\circ} \mathrm{C}\right)$ known to induce virulence in R11. The algal populations were monitored using flow cytometry and pulse-amplitude modulated fluorometry. Cultures of algae without bacteria remained healthy at $18^{\circ} \mathrm{C}$, but lower cell counts in control cultures at $25^{\circ} \mathrm{C}$ indicated some stress at the elevated temperature. Both the $\mathrm{C}$ (coccolithbearing) and $S$ (scale-bearing swarming) cell types of $E$. huxleyi experienced a rapid decline resulting in apparent death when co-cultured with $\mathrm{R} 11$ at $25^{\circ} \mathrm{C}$, but had no effect on $\mathrm{N}$ (naked) cell type at either temperature. R11 had no initial negative impact on $\mathrm{C}$ and $\mathrm{S}$ type $\mathrm{E}$. huxleyi population size or health at $18^{\circ} \mathrm{C}$, but caused death in older co-cultures. This differential effect of R11 on its host at 18 and $25^{\circ} \mathrm{C}$ suggest it is a temperature-enhanced opportunistic pathogen of $E$. huxleyi. We also detected caspaselike activity in dying $C$ type cells co-cultured with $\mathrm{R} 11$, which suggests that programmed cell death plays a role in the death of $E$. huxleyi triggered by R11 - a mechanism induced by viruses (EhVs) and implicated in E. huxleyi bloom collapse. Given that E. huxleyi has recently been shown to have acquired resistance against EhVs at elevated temperature, bacterial pathogens with temperature-dependent virulence, such as R11, may become much more important in the ecology of $E$. huxleyi in a warming climate.

\footnotetext{
Keywords: Emiliania huxleyi, Ruegeria, roseobacter, ocean warming, marine pathogen, temperature-enhanced virulence, climate change, phytoplankton
}

\section{INTRODUCTION}

Ocean warming is one of the largest contemporary threats to the stability of the marine ecosystem. Since the 1990s, the average global sea surface temperature (SST) has been reported to be rising an increase as dramatic as $4^{\circ} \mathrm{C}$ in some regions - and the rate of increase continues to climb (Smith et al., 2008). In the last century, there has been a global decline in phytoplankton which 
is strongly correlated to increasing SST (Boyce et al., 2010). This trend is disturbing, given the fact that phytoplankton form the base of the marine food web, and account for over half of the earth's primary productivity annually (Behrenfeld et al., 2001).

Emiliania huxleyi (Prymnesiophyta) is a ubiquitous marine phytoplankton and is the most common representative of the extant coccolithophores (Paasche, 2002). The life cycle of E. huxleyi alternates between diploid C type cells (nonmotile coccolith bearing) and haploid $S$ type cells (flagellated with organic scales), both of which are capable of propagating indefinitely via mitosis (Paasche, 2002). There is indirect evidence that $\mathrm{S}$ cells are generated through meiosis of $\mathrm{C}$ cells, and conversely, $\mathrm{C}$ cells are regenerated through syngamy of $\mathrm{S}$ cells; however, neither of these processes has been directly observed (Green et al., 1996; Paasche, 2002; von Dassow et al., 2009). A third, less common cell type, also exists - diploid non-motile $\mathrm{N}$ (naked) cells. These are thought to be naturally occurring mutants of $\mathrm{C}$ cells lacking the ability to produce coccoliths (Paasche, 2002; Frada et al., 2012).

Emiliania huxleyi is a model organism and has been studied extensively due to its significant role in global biogeochemical cycles (Simó, 2004). As a major producer of dimethylsulfoniopropionate (DMSP), the most abundant source of organic sulfur in the ocean, E. huxleyi is hypothesized to play a role in regulating earth's climate (Charlson et al., 1987; Ayers and Cainey, 2007). Under conditions that promote increased growth in E. huxleyi (increased temperature, increased availability of carbon for photosynthesis, etc.), DMSP production is increased (Ayers and Cainey, 2007). DMSP is degraded to dimethyl sulfide (DMS) by bacteria and phytoplankton, and this serves as the main contributor of cloud condensation nuclei (CCN) in marine environments (Charlson et al., 1987; Ayers and Cainey, 2007; Reisch et al., 2011). An increase in CCN production may lead to increased cloud cover and a subsequent increase in albedo, which has a cooling effect on atmospheric temperature (Charlson et al., 1987; Ayers and Cainey, 2007). However, this feedback hypothesis is highly debated (Quinn and Bates, 2011). Recent work has shown that the production of DMS by E. huxleyi cultures decreases at high $\mathrm{CO}_{2}$ concentrations in mesocosm experiments (Webb et al., 2016). This indicates that one of the marine environments temperature regulation mechanisms may be hindered by anthropogenic $\mathrm{CO}_{2}$ emissions.

Emiliania huxleyi also plays a unique role in carbon cycling. In addition to organic photosynthate production, E. huxleyi produces elaborate calcium carbonate disks (coccoliths) that cover its cells. Although the function of these coccoliths remains unclear, they may aid in UV protection (Gao et al., 2009). During the natural senescence (Voss et al., 1998; Chow et al., 2015) and virally induced (Wilson et al., 2002) death of an E. huxleyi cell, its coccoliths are shed. These calcite coccoliths are denser than the surrounding seawater, so they sink and are eventually deposited in the deep ocean where they are essentially removed from the carbon cycle (Schmidt et al., 2013). Since E. huxleyi displays a lifestyle in which expansive blooms - sometimes hundreds of thousands of square kilometers in size - appear suddenly and unpredictably, then collapse rapidly (Brown and Yoder, 1994), the influence of this phytoplankton on the sulfur and carbon cycles, as well as the proximate biological ecosystem, is maximized during these bloom events. Because of these major roles in global processes, it is essential to understand the ecology of such an influential organism.

Emiliania huxleyi lives in close association with a diverse assemblage of microbes (Green et al., 2015). This microbial community is defined by complex and intimate metabolic exchange and communication (Sapp et al., 2007). Some members of this microbial consortium are mutualistic. For example, E. huxleyi lacks the ability to synthesize vitamin B12 - a nutrient essential to its growth - however, it has been shown that it is able to survive in culture due to the exogenous production of vitamin B12 by a closely associated bacterium (Helliwell et al., 2011).

Conversely, several microbes associated with E. huxleyi are pathogenic. Bloom collapse has been attributed to outbreaks of EhVs - members of the Phycodnaviridae, a group of viruses known to infect microalgae (Wilson et al., 2009). The EhVs elicit death in E. huxleyi by up-regulating metacaspase activity and causing the associated caspase-like programmed cell death (PCD) of the alga (Bidle et al., 2007). The role of metacaspases and PCD in the defense of land plants to microbial pathogens has been repeatedly characterized (Lam et al., 2001). The same type of response has been suggested for E. huxleyi to prevent outbreaks of disease in large clonal populations (Bidle et al., 2007).

The roseobacter clade ( $\alpha$-Proteobacteria) is one of the most abundant bacterial groups present during E. huxleyi blooms (second only to SAR lineages; Gonzalez et al., 2000), and contains several pathogenic representatives. One such representative has been demonstrated to be the causative agent in the formation of gall-like tumors on Prionitis lanceolata (Rhodophyta; Ashen and Goff, 1998). Additionally, the roseobacter clade also contains the only known bacterial pathogen of E. huxleyi - Phaeobacter gallaeciensis - that produces potent algaecides in response to p-coumaric acid, a senescent signal in plants (Seyedsayamdost et al., 2011).

Another example of an algaecidal roseobacter is Ruegeria sp. R11 (syn. Nautella sp. R11; Fernandes et al., 2011), which causes bleaching disease in the habitat forming Delisea pulchra a red macroalgae native to the waters surrounding southern Australia (Case et al., 2011). The ability of R11 to cause bleaching events in D. pulchra has been demonstrated in both field and laboratory experiments to be temperature-dependent, with the disease only presenting at elevated temperature (Case et al., 2011). R11 was originally isolated from D. pulchra in the Tasman Sea (Case et al., 2011), one of the global hot spots for E. huxleyi blooms (Brown and Yoder, 1994). The present study aims to test the pathogenicity of R11 on E. huxleyi, a ubiquitous microalgae, which blooms in regions overlapping with $D$. pulchra's geographical distribution (western and southern Australia, and New Zealand; Huisman, 2000), and to assess the role a warming ocean might play in this interaction. Bacterialmacroalgal symbioses have been studied in detail, however, very few bacterial-microalgal interactions have been described (Egan et al., 2013).

It has been predicted that ocean warming will increase the frequency and severity of pathogenic attacks (Harvell et al., 2002). Consequently, it is essential to study the effects of shifting 
temperature on the biotic interactions of ecologically important organisms, like E. huxleyi. In the present study, we demonstrate that R11 is a temperature-enhanced pathogen of both the C and S cell types of E. huxleyi, but not $\mathrm{N}$ cell type, and that a caspase-like response is induced by $\mathrm{R} 11$ in the $\mathrm{C}$ cells at elevated temperature, which results in precipitous algal death.

\section{MATERIALS AND METHODS}

\section{Growth and Maintenance of Algal and Bacterial Strains}

Three axenic strains of Emiliania huxleyi were obtained from the Provasoli-Guillard National Centre for Marine Algae and Microbiota (NCMA): a C type diploid coccolith-bearing strain CCMP3266; an S type haploid sexual strain - CCMP3268; and an $\mathrm{N}$ type diploid bald strain - CCMP2090. All strains were maintained in L1-Si media (Guillard and Hargraves, 1993) at $18^{\circ} \mathrm{C}$ in a diurnal incubator (8:16 h dark-light cycle). Algal cultures and media were checked for bacterial contamination prior to use in experiments by microscopic observations and by inoculation onto $1 / 2$ marine agar (18.7 g Difco Marine Broth 2216 supplemented $9 \mathrm{~g} \mathrm{NaCl}$ and $15 \mathrm{~g}$ Difco agar in $1 \mathrm{~L}$ ). All strains were grown statically for 5 days in the $18^{\circ} \mathrm{C}$ incubator under the same light-dark regimen under which they were maintained. These incubation periods allowed the cultures to reach early-log phase prior to the start of an experiment.

The bacterium, Ruegeria sp. R11, was maintained on $1 / 2$ marine agar at $30^{\circ} \mathrm{C}$. It was grown to stationary phase in $5 \mathrm{~mL} 1 / 2$ marine broth (18.7 g Difco Marine Broth 2216 supplemented $9 \mathrm{~g} \mathrm{NaCl}$ ) in a shaking incubator $(160 \mathrm{rpm})$ at $21.5^{\circ} \mathrm{C}$ for $24 \mathrm{~h}$ prior to experiments.

\section{Control Cultures and Co-cultures}

For each algal strain tested, control cultures of the algae alone and Ruegeria sp. R11 alone, as well as a co-culture of R11 and algae, were prepared as previously described by Bramucci et al. (2015). Briefly, a stationary phase culture of R11 was grown, washed twice by centrifugation and re- in L1-Si media before undergoing a serial dilution in L1-Si to the $10^{2} \mathrm{cfu} / \mathrm{mL}$ (cells are diluted to the correct order of magnitude and the exact initial cell concentration is calculated from cfu counts). To prepare the co-culture, an early log-phase culture (5-dayold, $10^{4}-0^{5}$ cells $/ \mathrm{mL}$ ) was mixed volumetrically $1: 1$ with the $10^{2}$ $\mathrm{cfu} / \mathrm{mL}$ R11. Control cultures of both R11 and the algae were prepared by mixing the respective culture volumetrically $1: 1$ with sterile L1-Si medium, to account for the $1 / 2$ dilution of the coculture. The controls and co-culture were then aliquoted in $1 \mathrm{~mL}$ volumes into 48-well microtiter plates (Becton, Dickinson and Company, Franklin Lakes, NJ, USA). Aliquots were dispensed in such a way that three independent replicates of each culture type could be sampled and sacrificed for each time point. This method allowed a time course experiment to be conducted using sacrificial sampling, eliminating the need for re-sampling and reducing the error involved in an experiment with diminishing culture volume (Bramucci et al., 2015).
Half of the microtiter plates were incubated at $18^{\circ} \mathrm{C}$, while the other half were incubated at $25^{\circ} \mathrm{C}$. The microtiter plates were then incubated statically ( $8: 16 \mathrm{~h}$ dark-light cycle) at the respective temperatures for 24 days. This protocol was carried out for each of the three algal strains tested.

\section{Fluorescence Measurements}

A pulse-amplitude-modulation (PAM) fluorometer (WATERPAM, Waltz, Effeltrich, Germany) was used to measure photosynthetic yield $\left(F_{\mathrm{V}} / F_{\mathrm{m}}\right)$ of cultures containing algae (Schreiber et al., 1986). On sampling days, all samples were taken at the mid-point of the dark cycle (at $4 \mathrm{~h}$ ) and diluted in L1Si media to within the detection range of the PAM fluorometer. Samples were kept in the dark and at the appropriate temperature $\left(18\right.$ or $25^{\circ} \mathrm{C}$ ) throughout sampling. For each sample, an initial dark adaption period of 3 min was administered, after which a saturating pulse was applied and the fluorescence readings were taken twice at intervals of $1 \mathrm{~min} 30 \mathrm{~s}$ to calculate the photosystem II (PSII) potential quantum yield $\left(F_{\mathrm{v}} / F_{\mathrm{m}}\right)$ - which indicates the efficiency of PSII (van Kooten and Snel, 1990). Duplicate readings of each sample were averaged and this average was used to determine the $F_{\mathrm{v}} / F_{\mathrm{m}}$ of each sample (in triplicate). After culture death occurred, artificial yield values were detected for some samples. Severe damage to the chloroplasts and calvin cycle has been shown to result in an artificially high yield (1998), and for this reason yield data were reported as not detectable for samples where both chlorophyll content and cell number indicated that the culture was dead. Data were analyzed using SigmaPlot 12.

\section{Enumerating Algal and Bacterial Population Density}

Algal samples were prepared for flow cytometry from control cultures and co-cultures. Cells were fixed for flow cytometry by incubating in the dark for $10 \mathrm{~min}$ with $0.6 \%$ glutaraldehyde. Cells were then flash-frozen in liquid nitrogen and stored at $-80^{\circ} \mathrm{C}$ until flow cytometry was performed using a FACSCalibur (Becton Dickinson, San Jose, CA, USA). A single replicate was randomly chosen and analyzed for each experimental day, as experimental variability was low. A $488 \mathrm{~nm}$ laser was used for excitation and a $670 \mathrm{~nm}$ laser was used for detection of chlorophyll. Chlorophyll autofluorescence was used for cellular enumeration. Cells were subsequently stained with SYBRgreen-I (Life Technologies, Carlsbad, CA, USA) for DNA detection $(520 \mathrm{~nm})$. Data were processed using FlowJo 9.2.

The R11 population density from co-culture experiments was enumerated by counting colony forming units ( $\mathrm{cfu}$ ) to enumerate planktonic R11 cells and those attached to E. huxleyi cells. Samples were first vortexed vigorously to remove R11 cells from E. huxleyi and reduce bacterial cell clumping. Then a dilution series was prepared in L1-Si media, plated on $1 / 2$ marine agar and incubated for 2 days at $30^{\circ} \mathrm{C}$.

\section{Caspase-Like Activity Measurement}

In vitro caspase-like IETDase (Ile-Glu-Thr-Asp) activity in E. huxleyi was measured as previously described by Bidle et al. (2007) with a few amendments. A single replicate was randomly 
chosen and analyzed for each experimental day. Briefly, aliquots of $850 \mu \mathrm{L}$ of control cultures and co-cultures were pelleted by centrifugation for $10 \mathrm{~min}$ at $14,000 \times g$ at $4^{\circ} \mathrm{C}$. The supernatant was removed, discarded and replaced with $0.1 \mathrm{~mL}$ sterile PBS. The tube containing the pellet and PBS was immediately flash-frozen in liquid nitrogen, and stored at $-80^{\circ} \mathrm{C}$ until processed. Pellets were resuspended and a subsample was analyzed for protein content using standard protein extraction (BCA protein assay, Pierce). The remaining sample was centrifuged and pellets were resuspended in caspase activity buffer according to manufacturer specifications (Caspase Activity Kit, EMB Millipore) and sonicated on ice. Cellular debris was pelleted $(16,000 \times g$, room temp, $2 \mathrm{~min}$ ) and cell lysates were incubated with IETD-AFC (IleGlu-Thr-Asp-7-amino-4-trifluoromethylcoumarin) according to the manufacturer's instructions. Extracts were then incubated for $4 \mathrm{~h}$ at $25^{\circ} \mathrm{C}$ as IETDase activity from the cell lysate produces a fluorescent product from cleavage of ETD-AFC. Fluorescence was measured every 10 min using a Spectra Max Gemini XS plate reader (excitation $400 \mathrm{~nm}$, emission $505 \mathrm{~nm}$ ). Caspase activity was successfully abolished (>90\%) with the irreversible caspase inhibitor z-VAD-FMK (z-Val-Ala-Aspfluoromethyl-ketone; Calbiochem).

In vivo detection of active caspase-like proteases was accomplished using a cell permeable fluorescently labeled active site inhibitor (Millipore: FITC-VAD-FMK). Labeled algal proteases were visualized with epifluorescence microscopy after in vivo cell staining. After staining, cells were pelleted by centrifugation for $5 \mathrm{~min}$ at $5,000 \times g$, gently suspended in sterile PBS according to manufactures instructions; cells were imaged within $5 \mathrm{~h}$ of staining. Epifluorescence microscopy was used to assess algal chlorophyll autofluorescence. Cells were also stained with DAPI (4',6-Diamidino-2-Phenylindole; Dihydrochloride; Life Technologies, Carlsbad, CA, USA) according to manufacturer's instructions. DAPI was used instead of SYBRgreen-I, as the emission spectrum of the latter overlaps with that of the caspase inhibitor.

\section{RESULTS}

\section{Population Dynamics of Emiliania huxleyi and Ruegeria sp. R11 in Co-culture}

Three cell types of E. huxleyi were tested for their interaction with R11 at 18 and at $25^{\circ} \mathrm{C}$. For each algal strain tested, control cultures of the algae alone and Ruegeria sp. R11 alone, as well as a co-culture of R11 and algae, were prepared as previously described by Bramucci et al. (2015).

\section{Coccolith-Bearing C Type E. huxleyi}

At $18^{\circ} \mathrm{C}$, C type E. huxleyi (CCMP3266) in co-culture with R11 remained healthy until 14 days, when death of CCMP3266 was observed (Figures 1A,C). The PSII potential quantum yield $\left(F_{\mathrm{v}} / F_{\mathrm{m}}\right)$ - a measure of photosynthetic efficiency hereafter referred to as yield (Schreiber, 1998) - of CCMP3266 in coculture began to drop from 12 to 14 days, and continued dropping until the damage to PSII resulted in an undetectable yield at 20 days, and did not recover at any subsequent time in the experiment (Figure 1A). Algal cell numbers followed a similar pattern, with a small decrease occurring from 12 to 14 days, and a greater decrease to near zero values between 16 and 20 days (Figure 1C). In contrast, control cultures of CCMP3266 at $18^{\circ} \mathrm{C}$ retained a consistently high yield and cell density throughout the experiment (Figures 1A,C).

Death was observed much earlier in the co-culture of CCMP3266 with R11 grown at $25^{\circ} \mathrm{C}$ compared to $18^{\circ} \mathrm{C}$ (Figures 1B,D). At $25^{\circ} \mathrm{C}$, the yield (Figure 1B) and algal cell density (Figure 1D) began to decline by 2 days and reached an undetectable level by 4 days (compared to 14 and 20 days at $18^{\circ} \mathrm{C}$ ). A small resurgence in cell density with high yield values was observed on 8 days, which was again undetectable by 12 days and remained so through the experiment (Figures 1B,D). Like those grown at $18^{\circ} \mathrm{C}$, control cultures of CCMP3266 at $25^{\circ} \mathrm{C}$ retained a consistently high yield throughout the experiment (Figure 1B). CCMP3266 cell density in control culture at $25^{\circ} \mathrm{C}$ was initially similar to the control culture at $18^{\circ} \mathrm{C}\left(1.4 \times 10^{6}\right.$ cells $/ \mathrm{mL}$ and $1.5 \times 10^{6}$ cells $/ \mathrm{mL}$, respectively, on 4 days), but later decreased on 6 and 8 days to approximately half of it's peak cell density and then experienced large oscillations around this number from 10 to 24 days (Figure 1D).

The R11 population density in co-culture with CCMP3266 at 18 and $25^{\circ} \mathrm{C}$ both increased from $10^{2} \mathrm{cfu} / \mathrm{mL}$ to $10^{7} \mathrm{cfu} / \mathrm{mL}$ (Figures 1E,F). However, the $25^{\circ} \mathrm{C}$ co-cultures reached this cell density faster (on 2 days) than the co-culture at $18^{\circ} \mathrm{C}$ (on 4 days; Figures 1E,F). At both temperatures, the R11 populations benefited from the presence of CCMP3266. At $18^{\circ} \mathrm{C}$, control R11 (bacteria alone) population density crashed by 2 days (Figure $1 \mathrm{E}$ ), while at $25^{\circ} \mathrm{C}$, the $\mathrm{R} 11$ population remained present, but experienced large oscillations from $10^{3}$ to $10^{6} \mathrm{cfu} / \mathrm{mL}$ for the remainder of the experiment (Figure 1F). The R11 control population remained present at a significant level throughout the experiment at $25^{\circ} \mathrm{C}$ but not $18^{\circ} \mathrm{C}$, a temperature it grows well at in $1 / 2$ marine broth, suggests that R11 does not thrive in L1Si media at $18^{\circ} \mathrm{C}$ due to the additive effects of a low nutrient medium and low temperature.

\section{Scale-Bearing Swarming S Type E. huxleyi}

Similar to the C cell type (CCMP3266), the co-culture of the $\mathrm{S}$ cell type (CCMP3268) with $\mathrm{R} 11$ at $18^{\circ} \mathrm{C}$ remained healthy until 10 days, after which death was observed (Figures 2A,C). The yield began to decline on 10 days, becoming negligible by 14 days and no recovery was observed by 24 days (Figure 2A). Both control (CCMP3268 alone) and co-culture S cell density experienced a rapid increase from 0 to 4 days, but declined after 6 days (Figure 2C). The CCMP3268 control culture cell density remained steady at this lower level for the remainder of the experiment (Figure 2C). However, the algal cell density of the co-culture kept declining, approaching zero by 12 days, where it remained until the end of the experiment (Figure 2C).

Death was observed much earlier in the co-culture of CCMP3268 with $\mathrm{R} 11$ at $25^{\circ} \mathrm{C}$ in comparison to $18^{\circ} \mathrm{C}$ (Figures 2B,D). At this higher temperature, the yield (Figure 2B) and cell count (Figure 2D) of the co-culture were similar to control values (no R11) on 2 days, but had crashed by 4 days. Algal cell density remained near zero for the remainder of the 


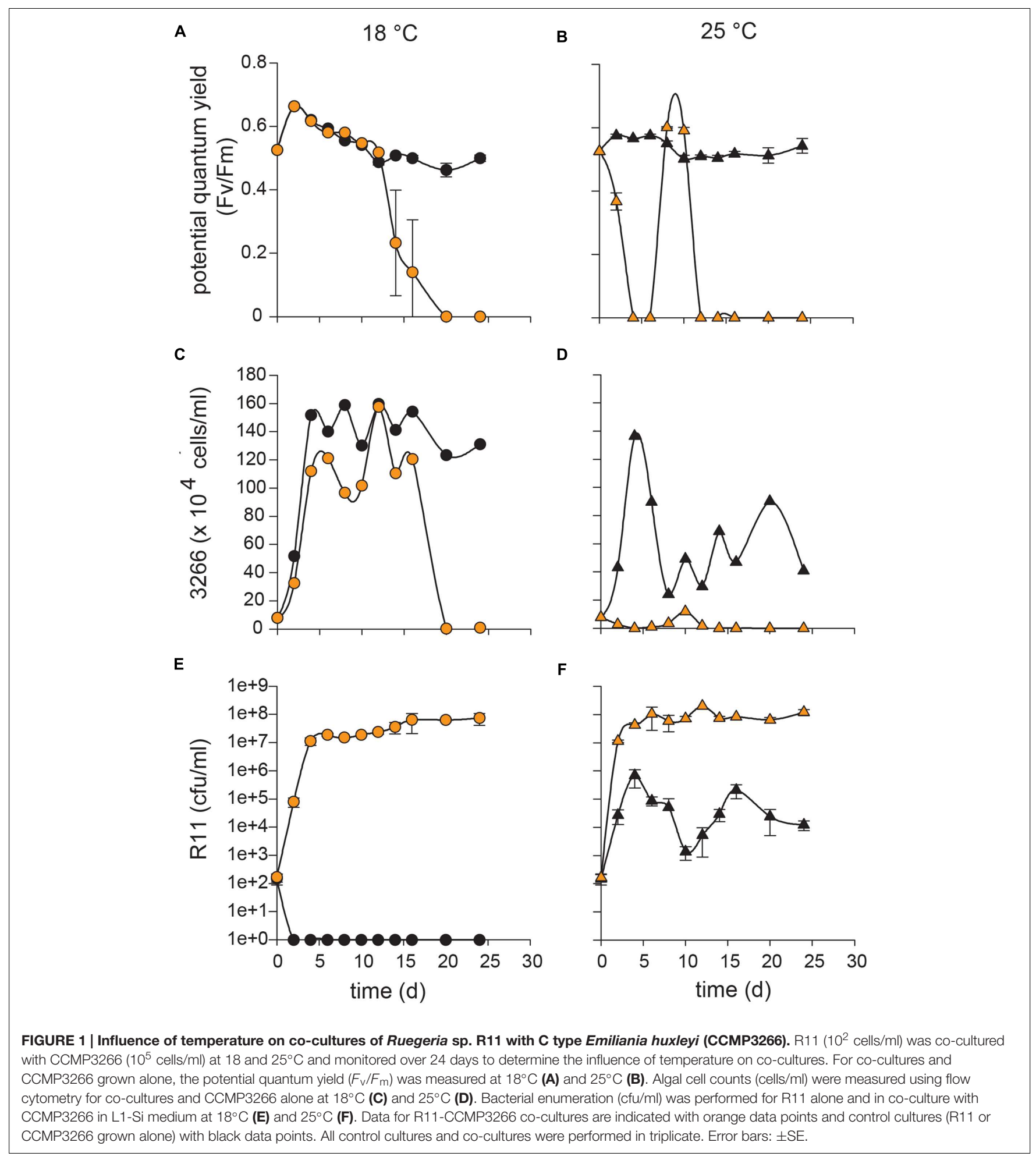

experiment (Figure 2D). Co-culture yield values also remained undetectable, except for an anomaly on 16 days where a single replicate gave a detectable reading (Figure 2B). This type of outlier is due to the nature of the sacrificial sampling method and was observed in replicate experiments (results not shown).
On a given sampling day, three replicates of the $1 \mathrm{~mL}$ wells are sacrificed and sampled for each culture type (algal control, bacterial control, and co-culture). At $25^{\circ} \mathrm{C}$, control cultures of CCMP3268 retained a high yield for 10 days after the death of the co-culture, falling significantly only on 16 days (Figure 2B). 


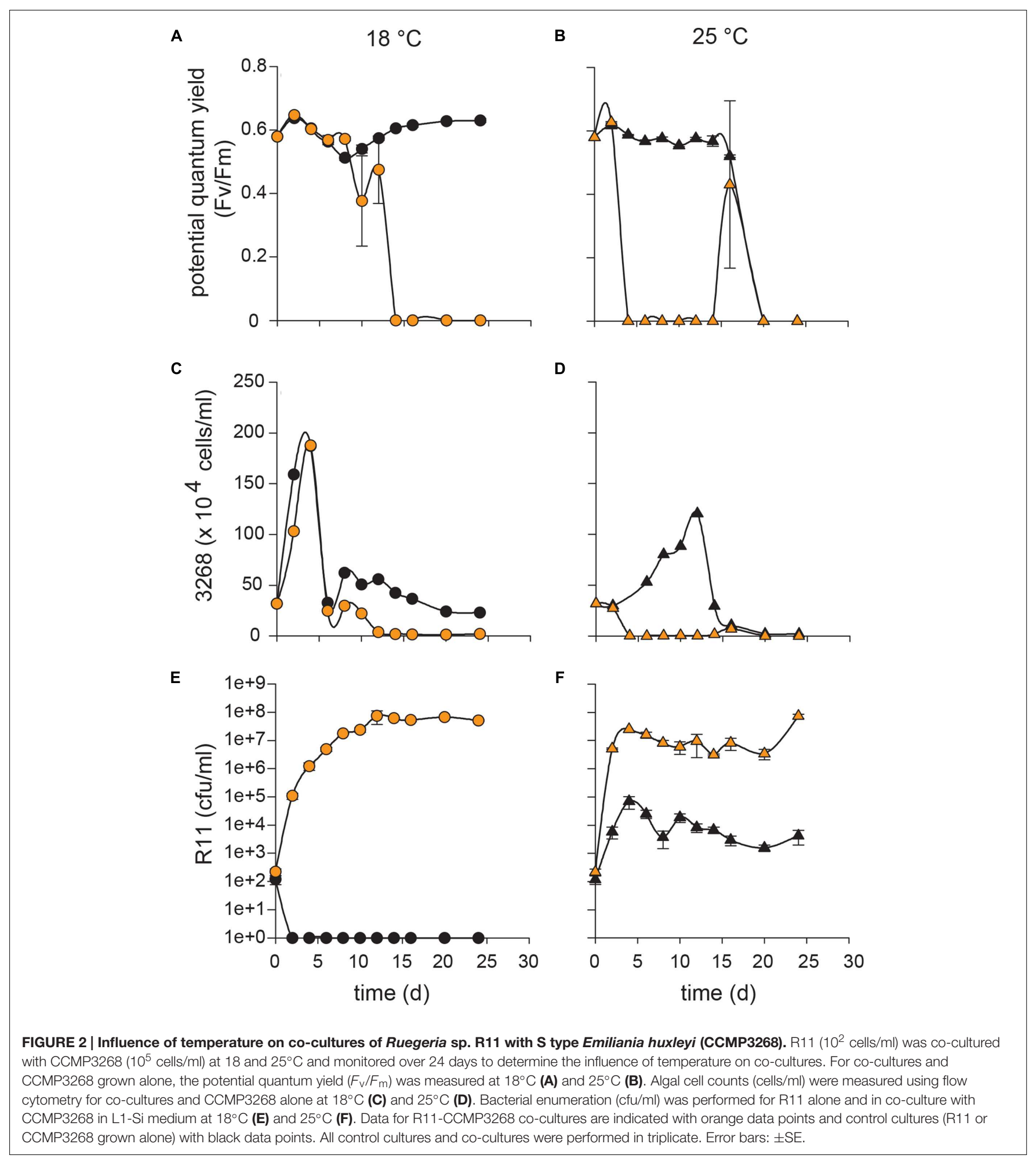

Compared to the control culture at $18^{\circ} \mathrm{C}$, which grew to $\sim 1.5 \times 10^{6}$ cells $/ \mathrm{mL}$ by 4 days and maintained this cell density throughout the experiment, the cell density of the CCMP3268 control culture at $25^{\circ} \mathrm{C}$ increased slowly, peaking at $\sim 1.3 \times 10^{6}$ cells $/ \mathrm{mL}$ on 12 days, after which it followed the same pattern as the yield (Figure 2D). Neither the yield, nor the cell count recovered by the end of the experiment.

$\mathrm{R} 11$ populations attained equally high density $\left(10^{7} \mathrm{cfu} / \mathrm{mL}\right)$ in co-culture with CCMP3268 at both 18 and $25^{\circ} \mathrm{C}$ (Figures 2E,F). Similar to the co-culture with CCMP3266, this level was 
achieved twice as quickly at 25 as at $18^{\circ} \mathrm{C}$ (Figures 2E,F). Control populations of $\mathrm{R} 11$ reached the same density as control bacterial populations from the CCMP3266 co-culture experiment, crashing rapidly at $18^{\circ} \mathrm{C}$ (on 2 days) and maintaining their population at $25^{\circ} \mathrm{C}$ at a lower level than in the co-culture (Figures 2E,F).

\section{Bald N Type E. huxleyi}

At 18 and $25^{\circ} \mathrm{C}$, both the co-culture and control culture of the $\mathrm{N}$ type E. huxleyi cells (CCMP2090) retained a high yield through 24 days (Figures 3A,B). Death was never observed in these cocultures. Co-cultures were established with the same density of $\mathrm{R} 11\left(10^{2} \mathrm{cfu} / \mathrm{mL}\right)$ and reached the same population density $\left(10^{7}\right.$ $\mathrm{cfu} / \mathrm{mL}$ ) as it did in co-culture with CCMP3266 and CCMP3268. Absolute numbers of R11 were not quantified at every time point within the experiment, but its presence was confirmed with drop plating of the co-culture on $1 / 2$ marine agar at every sampling point. Flow cytometry was not run for this cell type, as no effect of co-culturing on yield or minimum fluorescence (a proxy for chlorophyll fluorescence) was observed.

\section{Observation of Algal Bleaching in E. huxleyi and Ruegeria sp. R11 Co-Cultures}

Since R11 is known to cause bleaching in the macroalga D. pulchra (Case et al., 2011), the bleaching effect of R11 on E. huxleyi was assessed using flow cytometry. R11 pathogenesis of E. huxleyi caused the loss of chlorophyll autofluorescence, or bleaching, of CCMP3266 (Figure 4) and CCMP3268 (Figure 5). At $18^{\circ} \mathrm{C}$, co-culture populations of CCMP3266 and CCMP3268 with $\mathrm{R} 11$ are indistinguishable from control populations (algae alone) at 12 and 8 days respectively, when the chlorophyll autofluorescence $(670 \mathrm{~nm})$ of cells was plotted against the forward scatter for both populations (Figures $4 \mathrm{~A}$ and $5 \mathrm{~A}$ ). On 14 and 10 days, when yield and cell density indicated the start of algal decline (Figures 1A,C and 2A,C), CCMP3266 and CCMP3268 cells lost chlorophyll autofluorescence, but retained forward scatter values (Figures 4B and 5B). This shows that the algae lose chlorophyll autofluorescence before cell size (i.e., lysis). This decrease in chlorophyll autofluorescence happened relatively gradually (compared to $25^{\circ} \mathrm{C}$ ), resulting in a 'smear' of cells in the process of losing chlorophyll on the scatter plot. On days where yield and cell density were near zero, a population of cells was present with the same forward scatter as control cultures, but almost all fluorescence (chlorophyll) was gone (Figures 4C and 5C).

At $25^{\circ} \mathrm{C}$, the decrease in chlorophyll content occurred more rapidly, and the gradual loss observed at $18^{\circ} \mathrm{C}$ is not present (Figures 4 and 5). Instead, the co-cultures appear to experience a rapid loss of fluorescence (chlorophyll) from populations similar to control cultures with no bacteria (same forward scatter and chlorophyll values), to populations of cells with the same forward scatter as control cultures, but a low level of fluorescence (chlorophyll) by the next time point (Figures 4 and 5).

As a secondary measure of cell death, cells were stained cells with SYBRgreen-I that stains DNA. The DNA content of cells decreased in both CCMP3266 (Supplementary Figure S1) and CCMP 3268 following the same general pattern as the chlorophyll bleaching. However, this process of DNA loss was slower and cells were observed microscopically to have DNA throughout the cytoplasm when co-cultured with R11, while control cells had a clear nucleus (Supplementary Figure S1).

\section{Measurement of Caspase-Like Activity in C Type E. huxleyi Co-Cultures with Ruegeria sp. R11}

The major known pathogens of E. huxleyi are viruses, which are collectively called E. huxleyi viruses (EhVs). Infection by these viruses triggers caspase-like activity (likely mediated by algal metacaspase activity), which coincides with death and production of viral particles in various diploid $\mathrm{N}$ type E. huxleyi strains (Bidle et al., 2007). Caspase-like activity has been observed in cells after the loss of their chlorophyll and therefore of the corresponding autofluorescence (Bidle et al., 2007). To determine if a bacterial pathogen of E. huxleyi would also trigger caspase-like activity, CCMP3266 was assayed for caspase-like IETDase (Ile-Glu-Thr-Asp) using the Caspase-8 Activity Kit (EMB Millipore). In the control cultures (E. huxleyi only) at 18 and $25^{\circ} \mathrm{C}$, a background level of caspase-like activity was present

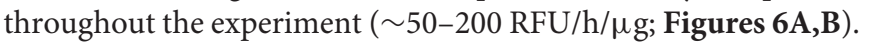
For CCMP3266 in co-culture with $\mathrm{R} 11$ at $18^{\circ} \mathrm{C}$, there was a slight (0.25- to 0.5 -fold) increase in caspase-like activity on 16,20 , and 24 days (time points at which the co-culture was dead or dying), compared to the control (Figure 6A). However, the caspase-like activity was a much greater in the co-culture at $25^{\circ} \mathrm{C}$ - a 3.5 -fold increase was observed at 2 and 4 days, and a twofold increase on 6 and 8 days (all days on which the co-culture was dead or dying; Figure 6B).

Caspase-like activity was directly visualized using microscopy of cells stained with a fluorescently labeled caspase-marker (FITC-VAD-FMK). Cells showing clear VAD labeling - an indicator of active caspase-like proteases - in both the 18 and $25^{\circ} \mathrm{C}$ R11-CCMP3266 co-cultures were characterized as having less or no chlorophyll and compromised cell integrity. The image in Figures $6 \mathrm{C}, \mathrm{D}$ is a representative cell taken from an $18^{\circ} \mathrm{C}$ R11-CCMP3266 co-culture at 14 days. This cell bears coccoliths, shows minimal autofluorescence (indicating a small amount of chlorophyll; Figure 6C) and displays caspase-like activity (Figure 6D). On the other hand, chlorophyll-containing cells (showing strong autofluorescence) were rare in declining R11CCMP3266 co-cultures. These were typical in young control cultures, however, some could be found even within the $25^{\circ} \mathrm{C}$ co-culture using microscopy (Supplementary Figure S2). In addition to significant chlorophyll autofluorescence, these cells were characterized by the presence of structural integrity and lack of visible FITC-VAD-FMK labeling. The image in Figures 6E,F was taken from 4 days R11-CCMP3266 co-culture at $25^{\circ} \mathrm{C}$ and displays a chlorophyll-containing cell (smaller and showing chlorophyll autofluorescence in red but lacking FITC-VAD-FMK labeling) and a cell displaying strong caspase activity (larger and staining green from FITC-VAD-FMK labeling but lacking autofluorescence from loss of chlorophyll). In this image, both 


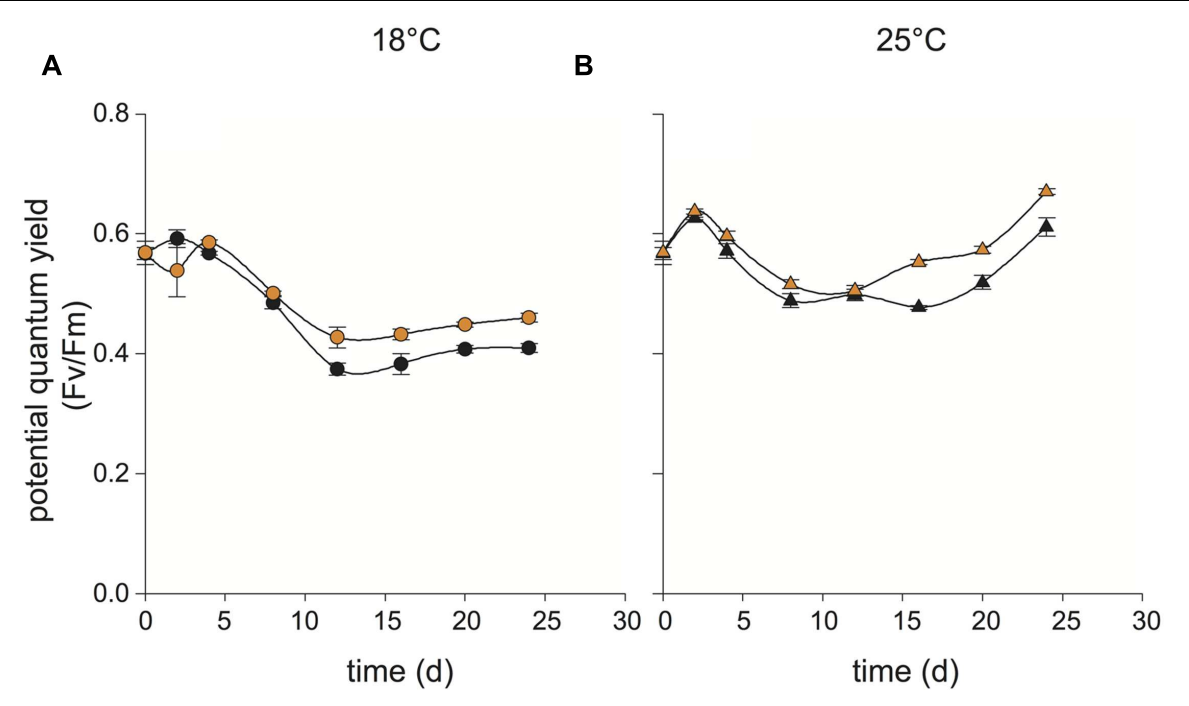

FIGURE 3 | Influence of temperature on co-cultures of Ruegeria sp. R11 with N type Emiliania huxleyi (CCMP2090). R11 (10² cells/ml) was co-cultured with CCMP2090 at 18 and $25^{\circ} \mathrm{C}$ and monitored over 24 days to determine the influence of temperature on co-cultures. For co-cultures and CCM2090 grown alone, the potential quantum yield $\left(F_{\mathrm{v}} / F_{\mathrm{m}}\right)$ was measured at $18^{\circ} \mathrm{C}(\mathbf{A})$ and $25^{\circ} \mathrm{C}(\mathbf{B})$. Data for R11-CCMP2090 co-cultures are indicated with orange data points and control cultures (CCMP2090 grown alone) with black data points. All control cultures and co-cultures were performed in triplicate. Error bars: \pm SE.

cells have lost their coccoliths, a normal result of senescence (Chow et al., 2015). In many cases, R11 cells were observed attached to E. huxleyi cells (Figures 6G,H).

\section{DISCUSSION}

\section{Ruegeria sp. R11 Pathogenicity Varies between Cell Types of Emiliania huxleyi}

The present study demonstrates that Ruegeria sp. R11 is a pathogen of E. huxleyi, but that this pathogenicity, or host resistance, is strain dependent. Both E. huxleyi CCMP3266 and CCMP3268 are killed when in co-culture with R11 (Figures 1 and 2, respectively). CCMP3268, an S type haploid flagellated cell, was originally isolated from cultures of CCMP3266, a C type diploid coccolith bearing cell isolated from the Tasman Sea, after part of the original culture of CCMP3266 was observed to undergo a shift to this haploid cell type (Frada et al., 2008; von Dassow et al., 2009). It is hypothesized that CCMP3268 is the sexual cell of CCMP3266. However, since neither meiosis nor syngamy has ever been directly observed, this cannot be confirmed. Given this relationship between CCMP3266 and CCMP3268, it follows that they should be similar in their sensitivity to pathogens unless the cell type conveyed resistance. Transcriptomic analyses have shown that these strains display $\sim 50 \%$ transcript similarity, with the major functional differences relating to motility and biogenic $\mathrm{CaCO}_{3}$ production - the haploid CCMP3268 cells are flagellated while the diploid CCMP3266 cells are coccolith bearing (von Dassow et al., 2009). However, it has been shown that while CCMP3266 is sensitive to the bloomcollapse causing EhVs, CCMP3268 is resistant due to a lack of host recognition by the virus (Frada et al., 2008). As opposed to the C or S type strains, bald N type E. huxleyi CCMP2090 is seemingly resistant to infection by R11 (Figure 3), although interestingly, CCMP2090 is susceptible to two of the major strains of EhV (EhV1 and EhV86; Fulton et al., 2014). Since the bacteria infects different cell types than the previously described EhVs, the complex interplay between these two algal pathogens will be important to understand as the ecology of E. huxleyi blooms.

It is unclear from the present study what is the key difference between the E. huxleyi strains that causes the observed variability in susceptibility to R11 infection, but there are several possibilities. CCMP2090 is the diploid axenic noncoccolith bearing (bald) isolate of the diploid coccolith bearing CCMP1516, which was collected off the coast of Ecuador, making it geographically distant from both CCMP3266 and R11, which were both isolated from the Tasman Sea. The ability of phylogenetically closely related strains of the Roseobacter clade to induce gall formation on species of Prionitis has been shown to be geographically specific - strains of gall-forming roseobacter isolated from infected Prionitis in one geographical area were unable to induce gall formation in closely related Prionitis from a distant geographical location (Ashen and Goff, 2000). Similarly, it has been demonstrated in land plants that geographically distant subpopulations of a single species can differ in their resistance/susceptibility to pathogens, likely due to decreased interbreeding (Thrall et al., 2001). Diploid cells of E. huxleyi have been shown to have a more complex transcriptome than haploid cells, suggesting that there may be greater phenotypic diversity between diploid strains (von Dassow et al., 2009) and thus greater diversity in their resistance to pathogens (i.e., CCMP3266 and CCMP2090 are both diploid strains). Additionally, the nature of the CCMP2090 cell - naked, lacking both coccoliths and organic scales - may contribute to the differences in sensitivity between strains. It may be that R11 has different levels of attachment 


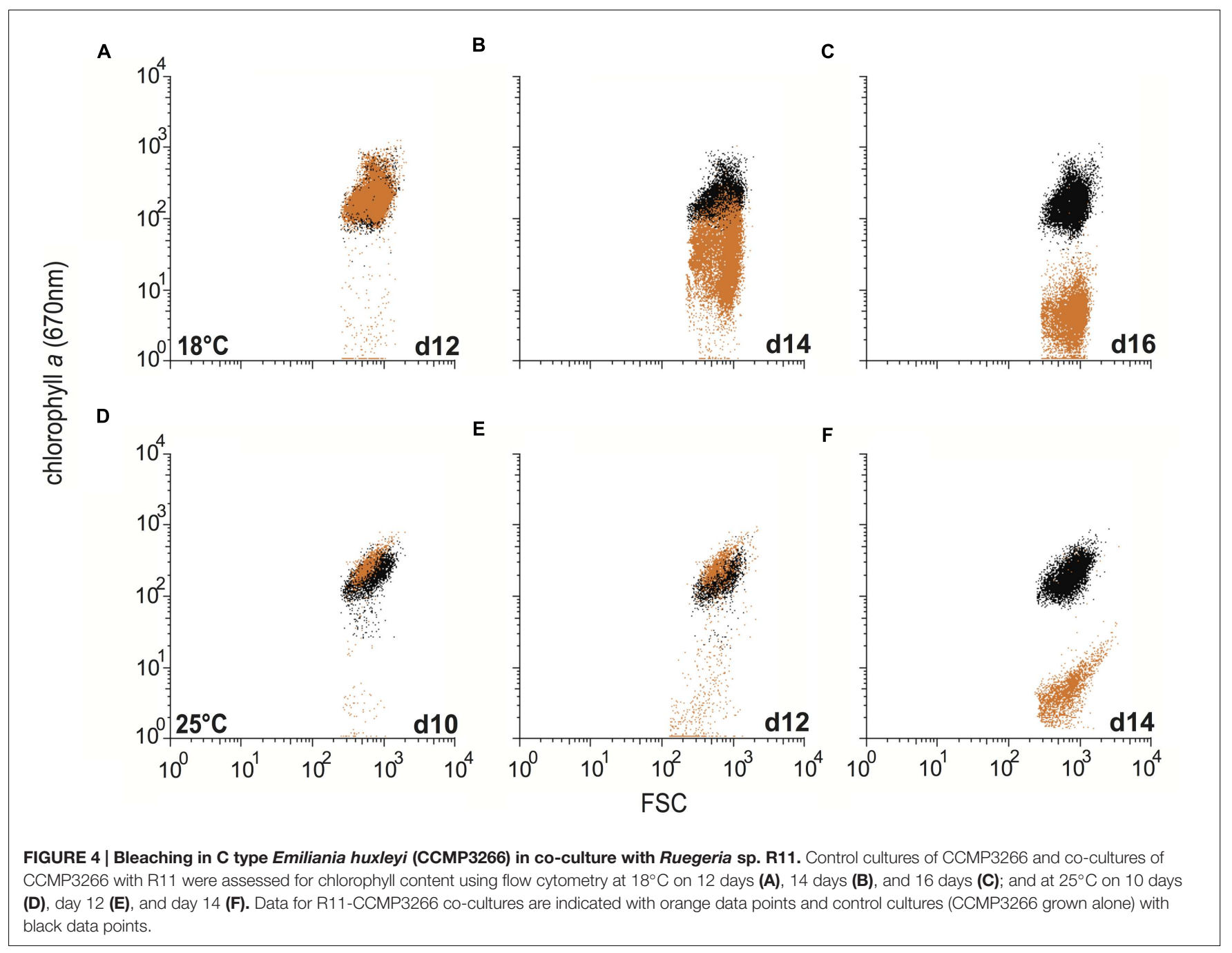

and/or colonization of the naked, organic or calcite liths covering E. huxleyi's cell surface.

$\mathrm{N}$ type cells, like CCMP2090, are thought to be a rare natural variant of C type cells, such as CCMP3266 (Paasche, 2002). However, if the mutation that causes the non-calcifying $\mathrm{N}$ cell type to occur provides an escape strategy from pathogens, the abundance and distribution patterns of this cell type may change in the future, and this would have consequences for the carbon sequestration role of E. huxleyi.

Although the mode of R11's pathogenesis is not currently known, several virulence factors have been identified, including the production of ammonia (inhibits photosynthesis), cytolytic toxins (lyses cells; Fernandes et al., 2011), and glutathione peroxidase (resists oxidative bursts from the host; Gardiner et al., 2015). It has also been hypothesized that the virulence of R11 may be related to its production of indole-3-acetic acid (IAA) - a phytohormone with various roles in the growth and development of land plants known to be produced by R11 (Fernandes et al., 2011). An extracellular excess of IAA causes hypertrophy and may increase the amount of algal exudates available to R11 (Fernandes et al., 2011). Interestingly, it has recently been shown that the exogenous addition of IAA causes increased cell permeability and cell size in CCMP2090, but not in CCMP3266 (Labeeuw et al., 2016). However, a difference in R11 virulence toward CCMP3266 is observed when tryptophan is added to stimulate IAA production, R11 killing CCMP3266 twice as fast ( 1 day compared to 2 days without the addition of tryptophan; Labeeuw et al., 2016). This is suggestive that IAA influences the virulence of R11 toward E. huxleyi. However, this effect is likely influenced by host factors, given that unlike CCMP3266, CCMP2090 cell size and permeability are responsive to IAA, but is not susceptible to the virulence of R11.

\section{The Virulence of R11 toward E. huxleyi Is Temperature-Enhanced}

The decrease in CCMP3266 and CCMP3268 health observed when grown in co-culture with $\mathrm{R} 11$ at $25^{\circ} \mathrm{C}$ compared to $18^{\circ} \mathrm{C}$ indicates that the pathogenicity of this bacterium toward them is temperature-enhanced. While R11 ultimately causes the death of CCMP3266 and CCMP3268 at both 18 and $25^{\circ} \mathrm{C}$, the course of the infection is accelerated at elevated temperature (Figures $\mathbf{1 A - D}$ and $\mathbf{2 A - D}$ ). This increase in the 


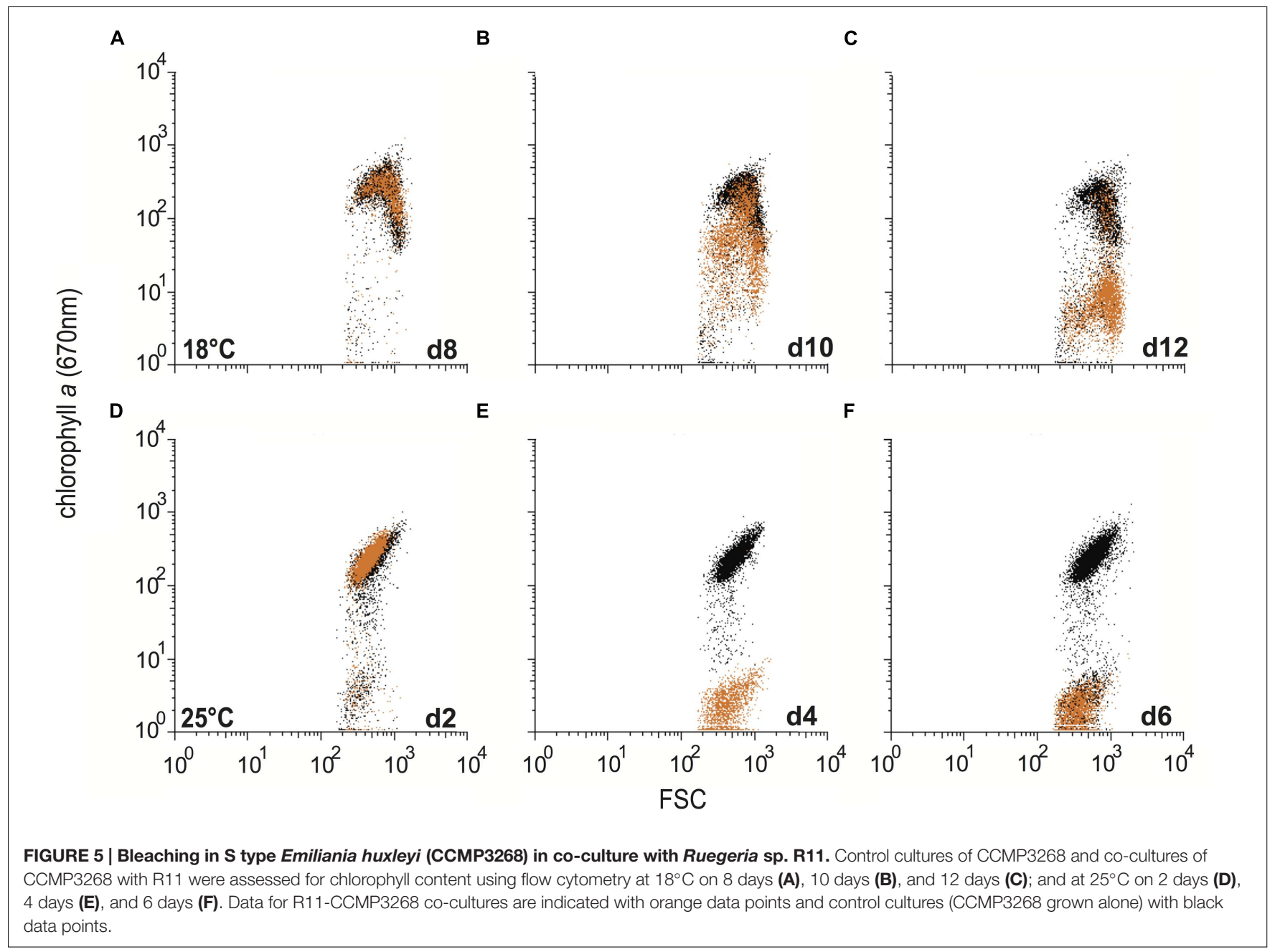

pathogenicity of R11 at elevated temperature cannot be explained by differential bacterial loads, as the R11 populations reached the same order of magnitude $\left(10^{7} \mathrm{cfu} / \mathrm{mL}\right)$ in co-culture with both algal strains at both temperatures (Figures 1E,F and $\mathbf{2 E}, \mathbf{F}$ ). Although R11 attains this carrying capacity 2-4 days earlier at $25^{\circ} \mathrm{C}$ than at $18^{\circ} \mathrm{C}$, this is also insufficient to explain the differences (Figures 1E,F and 2E,F). With CCMP3266, the initial drop in algal yield at $25^{\circ} \mathrm{C}$ occurs on the same day that R11 cell density reach their carrying capacity, while at $18^{\circ} \mathrm{C}$, algal death in co-culture does not begin until 10 days after the carrying capacity of R11 is reached (Figure 1). With CCMP3268, the timelines are slightly closer together, with the death of the $25^{\circ} \mathrm{C}$ co-culture beginning 2 days after $\mathrm{R} 11$ cell density reached carrying capacity and the death of the $18^{\circ} \mathrm{C}$ co-culture beginning 4 days after R11 carrying capacity had been reached (Figure 2).

The differences in timeline leading to death also cannot be explained by differences in the photosynthetic health of the algae at the two temperatures. CCMP3266 control cultures displayed equal yield values at both temperatures for the duration of the experiment (Figures 1A,B). CCMP3268 control cultures also maintained equivalent yield values at both 18 and $25^{\circ} \mathrm{C}$, until the control culture experienced death starting on 16 days (Figures 2A,B).

Taken together, these results support the hypothesis that the virulence of R11 on E. huxleyi is temperature-enhanced. This is in keeping with the original Delisea pulchra-R11 model of virulence in which R11 was pathogenic to D. pulchra at $24^{\circ} \mathrm{C}$, but not pathogenic at $19^{\circ} \mathrm{C}$ (Case et al., 2011). Temperatureenhanced bacterial pathogens have been linked to several other algal diseases including 'white tip disease' in Gracilaria conferta in which a bacterial isolate was found to be the causative agent and that increasing temperature above $20^{\circ} \mathrm{C}$ increased the rate of infection (Weinberger et al., 1994). Another example of temperature-enhanced virulence in the marine environment can be found in the bleaching of the coral Pocillopora damicornis by the bacterium Vibrio coralliilyticus, triggered by elevated temperature (Kushmaro et al., 1996; Ben-Haim et al., 2003; Rosenberg et al., 2009). In fact, this temperature-induced bleaching results from an attack by $V$. coralliilyticus on the zooxanthellae algal symbionts living within the coral tissue (BenHaim et al., 2003). It appears that the increased pathogenicity in this case was due to both the increased expression of virulence factors and a possible increase in sensitivity of the algae to 

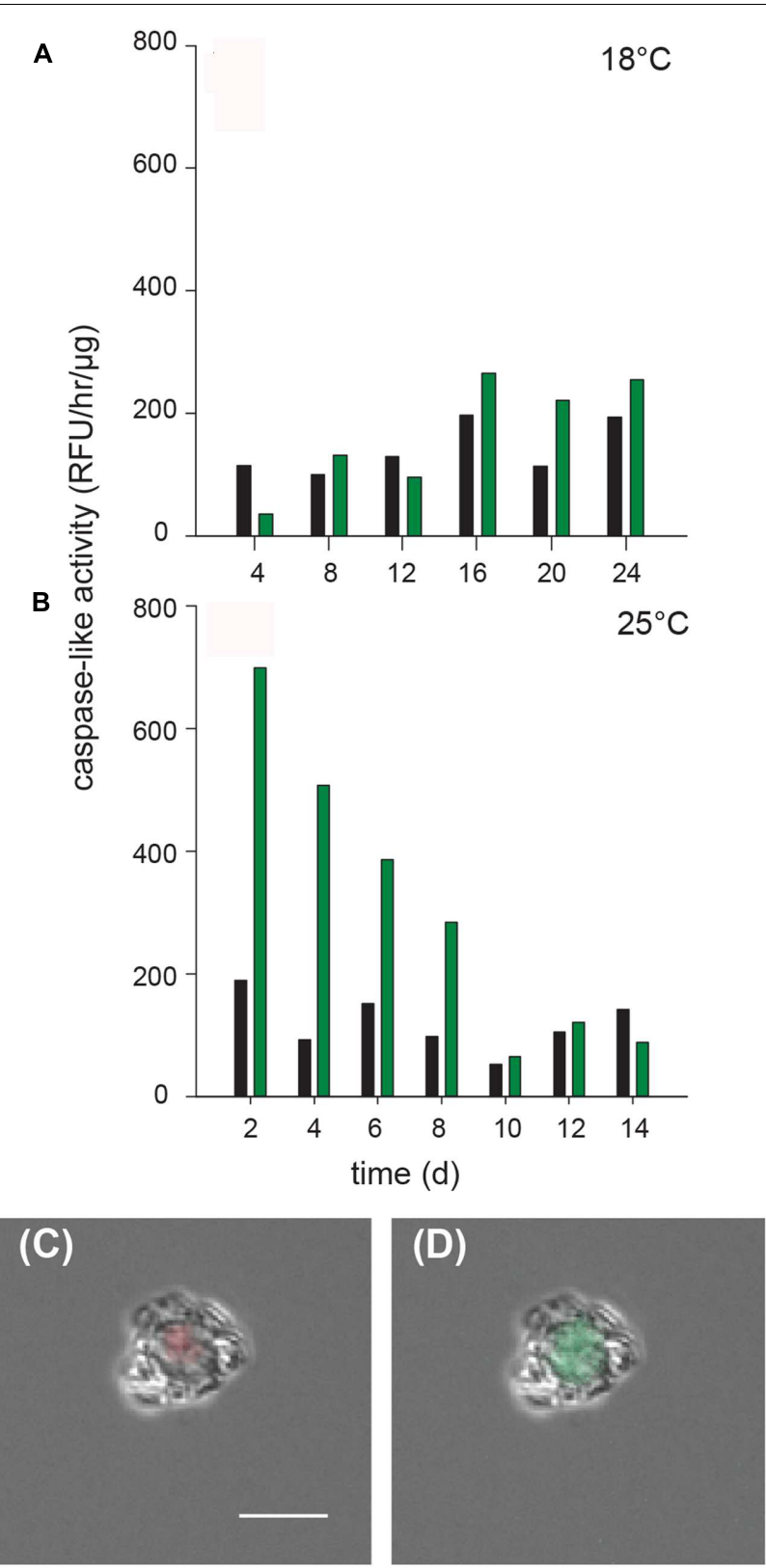
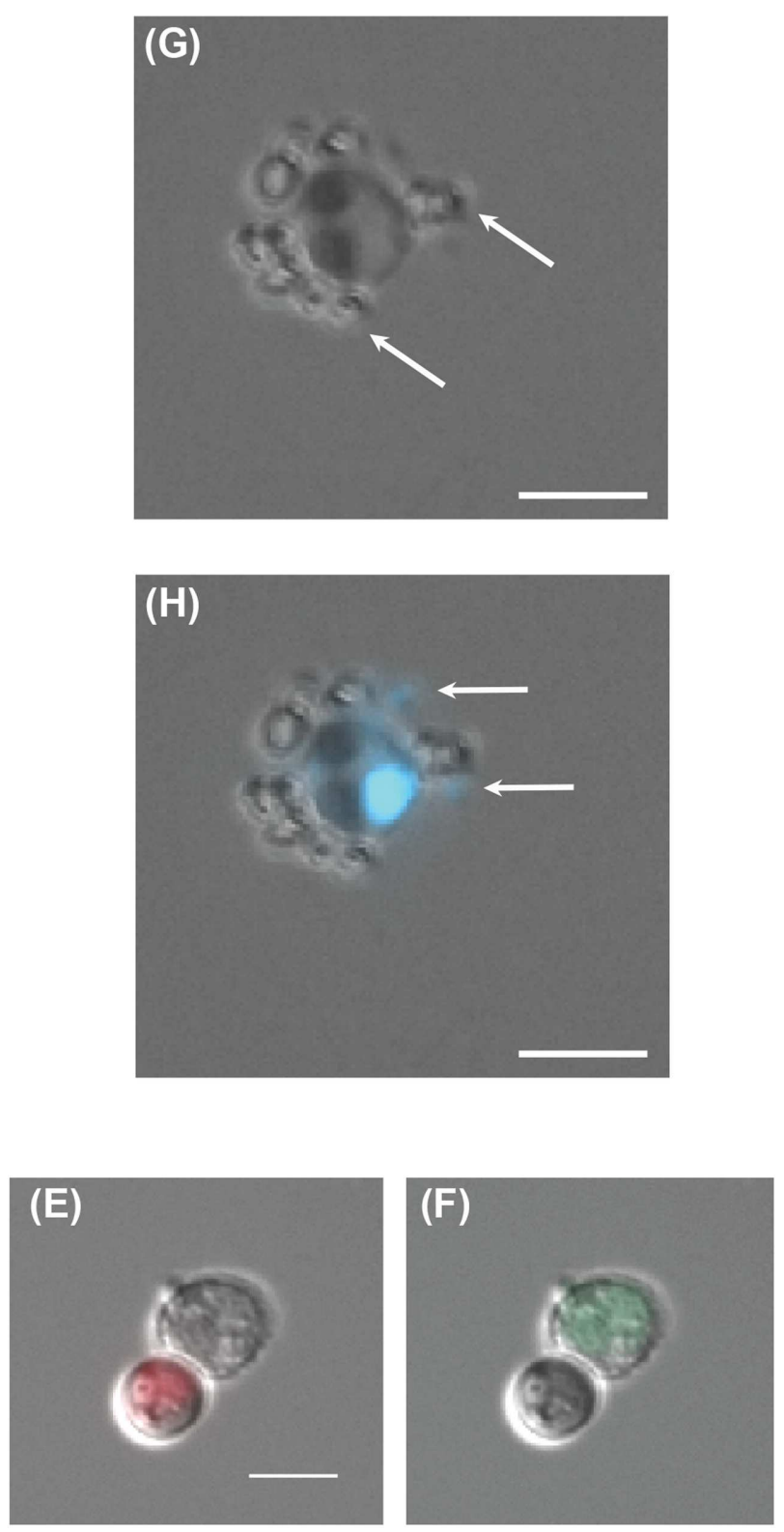

FIGURE 6 | Detection of caspase-like activity in C type Emiliania huxleyi (CCMP3266) in co-culture with Ruegeria sp. R11. R11 (10² cells/ml) was co-cultured with CCMP3266 $\left(10^{5} \mathrm{cells} / \mathrm{ml}\right)$ at 18 and $25^{\circ} \mathrm{C}$ to determine the influence of temperature on the degree of IETDase activity detected in CCMP3266 throughout the co-culture with R11. In vitro IETDase activity was measured (Caspase Activity Kit, EMB Millipore) at $18^{\circ} \mathrm{C}$ for CCMP3266 grown alone and in co-culture with R11 (A); and at 25 $\mathrm{C}$ for CCMP3266 grown alone and in co-culture with R11 (B). Data for R11-CCMP3266 co-cultures are indicated with green bars and control cultures (CCMP3266 grown alone) with black bars. Chlorophyll autofluorescence (red) was monitored microscopically in CCMP3266 cells at $18^{\circ} \mathrm{C}$ (C) and $25^{\circ} \mathrm{C}$ (E). In vivo detection of active capsase-like molecules (green) was monitored microscopically in cells stained with CaspACE (in situ VAD-marker: FITC-VAD-FMK) at $18^{\circ} \mathrm{C}$ (D) and at $25^{\circ} \mathrm{C}$ (F). DIC imaging shows cells bearing coccoliths (individual coccoliths indicated with 'Co') and DNA within algal and bacterial cells is stained with DAPI (G) and attached R11 cells are distinguished from coccoliths as bacteria contain DAPI stained DNA (bacteria indicated with 'R11') (H). The scale bar is $5 \mu \mathrm{m}$.

pathogen attack due to temperature stress (Kushmaro et al., 1996; Ben-Haim et al., 2003; Rosenberg et al., 2009).

In the present study, there is evidence of temperature stress in CCMP3266 and CCMP3268 at $25^{\circ} \mathrm{C}$, as there were marked differences in the algal population size and dynamics at 18 and $25^{\circ} \mathrm{C}$. For CCMP 3266 at $25^{\circ} \mathrm{C}$, the population size initially followed the same trajectory as the culture at $18^{\circ} \mathrm{C}$, reaching nearly the same peak cell density, but subsequently dropping to around half the density of the $18^{\circ} \mathrm{C}$ culture, where it stabilized for the remainder of the experiment (Figures 1C,D). For 
CCMP3268, the control culture at $25^{\circ} \mathrm{C}$ followed a completely different trajectory to the $18^{\circ} \mathrm{C}$ control culture, slowly increasing to a peak only two thirds the density of the maximum at $18^{\circ} \mathrm{C}, 8$ days later (Figures 2C,D). After this peak, cell density dropped sharply and remained near zero for the remainder of the experiment.

The fact that the cell densities were lower at $25^{\circ} \mathrm{C}$ for both CCMP3266 and CCMP3268 likely indicates temperature stress. The reported temperature range of E. huxleyi is highly variable (spanning 6-26 C; Rhodes et al., 1995; Paasche, 2002; Daniels et al., 2014), with marked differences in temperature optima reported even between strain clones (Paasche, 2002). In the present study, while cultures of both CCMP3266 and 3268 grow normally at $18^{\circ} \mathrm{C}$ (with a rapid log phase and a stable stationary phase), they both display altered dynamics at $25^{\circ} \mathrm{C}$ (slow initial growth rate and low or un-sustained stationary phase), which is near the upper limit of the species' temperature range. However, $25^{\circ} \mathrm{C}$ is an ecologically relevant temperature for these strains, as current SST in the Tasman Sea, where both CCMP3266/3268 and $\mathrm{R} 11$ originate, regularly reaches $25^{\circ} \mathrm{C}$ in the austral summer. This area - sometimes referred to as the 'Tasman Hot Spot' is predicted to have a rate of SST warming 3-4 times the global average (Oliver et al., 2014). Additionally, a metagenomic study has shown that EhVs are absent from populations of E. huxleyi in warm equatorial waters (von Dassow et al., 2015). This raises the possibility that regions likely to be even warmer in the future, such as the Tasman Sea, which currently host populations of E. huxleyi infected with EhVs, may soon represent a niche open to new pathogens such as R11.

It is unclear from the data presented whether the cause of the increase in pathogenicity of $\mathrm{R} 11$ at $25^{\circ} \mathrm{C}$ was the result of increased susceptibility of E. huxleyi, or was due to an increase in the production of virulence factors by R11 at elevated temperature, or a combination of the two factors. Plant pathogens are known to be triggered by temperatures outside the optimal range for host growth - in other words, by temperatures at which the defenses of the host may be compromised (Smirnova et al., 2001). For example, the blight pathogen Pseudomonas syringae significantly increases production of a phytotoxin at $18^{\circ} \mathrm{C}\left(7-10^{\circ} \mathrm{C}\right.$ below the growth optimum of its host; Budde and Ullich, 2000).

It is possible that R11 is an opportunistic pathogen, as its host range appears to be broad - including a red macroalga (Case et al., 2011) and a haptophyte (present study). For a pathogen with diverse hosts, a versatile strategy of triggering virulence might be to sense the stress of a host directly, instead of sensing the conditions that would cause a host's defenses to be compromised. This is a mechanism known to exist in Phaeobacter gallaeciensis BS107, another member of the Roseobacter clade. P. gallaeciensis produces algaecides in response to $p$-coumaric acid ( $p \mathrm{CA})-$ produced by E. huxleyi and thought to be a product of senescence (Seyedsayamdost et al., 2011). However, R11 is unlikely to use this particular molecule as a cue, since the addition of $p C A$ did not stimulate a change in its production of small molecules (Seyedsayamdost et al., 2011). The evidence from the present study - the fact that R11 displays a broad host range and increased virulence under conditions at which the host displays evidence of temperature stress - supports the hypothesis that R11 is an opportunistic pathogen.

\section{Ruegeria sp. R11 Causes Bleaching in E. huxleyi}

Bleaching - the loss of pigmentation - is a common phenomenon in marine corals and macroalgae (Jenkins et al., 1999; Douglas, 2003; Egan et al., 2013). In corals, this color loss refers to the death or loss of the symbiotic algae that live within the coral's tissue - a temperature-dependent effect often linked to bacterial infection that ultimately leads to the death of coral host (Kushmaro et al., 1996; Ben-Haim et al., 2003; Rosenberg et al., 2009). In macroalgae, the bleaching effect is due to the degradation of photosynthetic pigment that, depending of the extent of the bleaching, may lead to the death of the whole organism. In the present study, a color change was clearly visible in dead or dying cultures of E. huxleyi. R11-E. huxleyi co-culture wells changed from green to white. This bleaching was also evident from the flow cytometry results (Figures 4 and 5). In the case of both CCMP3266 (Figure 4) and CCMP3268 (Figure 5), during culture death, cells maintained their size (forward scatter) but lost their chlorophyll $\alpha$ content over 2 days at $25^{\circ} \mathrm{C}$ (Figures $4 \mathrm{D}-\mathrm{F}$ and 5D-F) or 4 days at $18^{\circ} \mathrm{C}$ (Figures $4 \mathrm{~A}-\mathrm{C}$ and $5 \mathrm{~A}-\mathrm{C}$ ).

Algal bleaching has been mostly attributed to temperature or UV stress alone (Jenkins et al., 1999), except in the case of D. pulchra, in which R11 is the temperature-dependent causative agent of the bleaching disease - D. pulchra grown without R11 at high temperature does not exhibit bleaching (Case et al., 2011). With the mentioned exception of D. pulchra, these studies do not assess the microbial community component of the system, and as such, bacterially mediated temperature induced bleaching in marine algae could be far more common than the literature reports. Here we demonstrate that it occurs in a microscopic unicellular haptophyte, distantly related, both phylogenetically and physiologically, to the red macroalgae in which it was previously found.

\section{Increased Caspase-Like Activity in Co-cultures of E. huxleyi and Ruegeria sp. R11}

While PCD was historically considered a phenomenon linked to multicellularity, it has recently been identified in several unicellular lineages, including coccolithophores (Bidle et al., 2007; Bidle and Kwityn, 2012). PCD is the genetically programmed deconstruction of cellular components by highly specific proteases. Caspases are cysteine proteases that cleave target substrate proteins containing the corresponding cleavage motif (4-5 amino acid motifs), resulting in apoptotic-PCD. While metacaspases differ from true caspases in both activity and specificity, there are reports of target substrates being similar between these enzymes (Sundström et al., 2009), as well as some reports of metacaspases exhibiting a biochemical activity (e.g., cleavage motifs) that is similar to that of true caspases (Madeo et al., 2002; Wilkinson and Ramsdale, 2011). Caspase-like activity was observed both in vivo and in vitro in the co-culture of CCMP3266 and R11. The method used in this study to quantify 
caspase-like activity in vitro detects the activity of IETDase caspases and structurally similar caspase-like proteases, some of which have been linked to increased metacaspase gene expression in the model EhV system (Bidle et al., 2007). Since the genome of E. huxleyi does not contain the genes encoding for caspases, but does contain 13 genes encoding for metacaspases (Choi and Berges, 2013), the activity detected here is likely due to the latter. Some background level of caspase-like activity was found in control cultures of CCMP3266 alone at both temperatures (Figures 6A,D), which has been previously reported in the viral experiments (Bidle et al., 2007; Bidle and Kwityn, 2012). A slight increase in activity from that background level was detected in co-cultures on days during which CCMP3266 was dead or dying at $18^{\circ} \mathrm{C}$, and a large increase on days during which CCMP3266 was dead or dying at $25^{\circ} \mathrm{C}$. This spike in caspase-like activity at $25^{\circ} \mathrm{C}$ might explain why death happened much earlier and more rapidly at elevated temperature. Bacterial pathogens of several land plant genera, including Solanum and Arabidopsis, have been shown to trigger the expression of metacaspases during the course of infection (Coll et al., 2011), but to our knowledge, caspase-like activity has not previously been shown to be induced in marine algae by a bacterial pathogen.

\section{CONCLUSION}

Natural blooms of E. huxleyi often experience a rapid collapse that has been attributed to lytic EhV infections causing PCD in the blooming algae (Vardi et al., 2009). However, it has recently been demonstrated that EhV strains become avirulent at increased temperature due to a change in the structure of the

\section{REFERENCES}

Ashen, J. B., and Goff, L. J. (1998). Galls on the marine red alga Prionitis laceolata (Halymeniaceae): specific induction and subsequent development of an algalbacterial symbiosis. Am. J. Bot. 85, 1710-1721. doi: 10.2307/2446505

Ashen, J. B., and Goff, L. J. (2000). Molecular and ecological evidence for species specificity and coevolution in a group of marine algal-bacterial symbioses. Appl. Environ. Microbiol. 66, 3024-3030. doi: 10.1128/AEM.66.7.3024-3030.2000

Ayers, G. P., and Cainey, J. M. (2007). The CLAW hypothesis: a review of the major developments. Environ. Chem. 4, 366-374. doi: 10.1071/EN07080

Behrenfeld, M. J., Randerson, J. T., McClain, C. R., Feldman, G. C., Los, S. O., Tucker, C. J., et al. (2001). Biospheric primary production during an ENSO transition. Science 291, 2594-2597. doi: 10.1126/science.1055071

Ben-Haim, Y., Zicherman-Keren, M., and Rosenberg, E. (2003). Temperatureregulated bleaching and lysis of the coral Pocillopora damicornis by the novel pathogen Vibrio coralliilyticus. Appl. Environ. Microbiol. 69, 4236-4242. doi: 10.1128/AEM.69.7.4236-4242.2003

Bidle, K. D., Haramaty, L., Barcelos, E., Ramos, J., and Falkowski, P. (2007). Viral activation and recruitment of metacaspases in the unicellular coccolithophore, Emiliania huxleyi. Proc. Natl. Acad. Sci. U.S.A. 104, 6049-6054. doi: 10.1073/pnas.0701240104

Bidle, K. D., and Kwityn, C. J. (2012). Assessing the role of caspase activity and metacaspase expression on viral susceptibility of the coccolithophore, Emiliania huxleyi (Haptophyta). J. Phycol. 48, 1079-1089. doi: 10.1111/j.15298817.2012.01209.x

Boyce, D. G., Lewis, M. R., and Worm, B. (2010). Global phytoplankton decline over the past century. Nature 466, 591-596. doi: 10.1038/nature09268

Bramucci, A. R., Labeeuw, L., Mayers, T. J., Saby, J. A., and Case, R. J. (2015). A small volume bioassay to assess bacterial/phytoplankton co-culture using glycosphingolipid required for viral recognition (Kendrick et al., 2014). This algal resistance is gained with only a $3^{\circ} \mathrm{C}$ increase in temperature - from 18 to $21^{\circ} \mathrm{C}$ (Kendrick et al., 2014).

In the context of a rapidly warming ocean, the emergence of temperature-induced resistance in E. huxleyi to its major pathogen may present an ecological gap. Our findings indicate that opportunistic bacterial pathogens like R11 with temperatureenhanced virulence have the ability to fill this gap and a transition between viral and bacterial disease outbreaks in E. huxleyi may be observed as SST continues to rise.

\section{AUTHOR CONTRIBUTIONS}

TM and RC conceived the research. AB, TM, and RC conducted the flow cytometry, TM, AB, and KY conducted the growth experiments. TM, AB, and RC drafted the manuscript. All authors have read and approved the manuscript.

\section{FUNDING}

This work was supported by Natural Sciences and Engineering Research Council of Canada (grant 402105) to RC.

\section{SUPPLEMENTARY MATERIAL}

The Supplementary Material for this article can be found online at: http://journal.frontiersin.org/article/10.3389/fmicb. 2016.00892

WATER-Pulse-Amplitude-Modulated (WATER-PAM) fluorometry. J. Vis. Exp. 97:e52455. doi: 10.3791/52455

Brown, C. W., and Yoder, J. A. (1994). Coccolithophorid blooms in the global ocean. J. Geophys. Res. 99, 7467-7482. doi: 10.1029/93JC02156

Budde, I. P., and Ullrich, M. S. (2000). Interactions of Pseudomonas syringae pv. glycinea with host and nonhost plants in relation to temperature and phytotoxin synthesis. Mol. Plant Microbe Interact 13, 951-961. doi: 10.1094/MPMI.2000.13.9.951

Case, R. J., Longford, S. R., Campbell, A. H., Low, A., Tujula, N., Steinberg, P. D., et al. (2011). Temperature induced bacterial virulence and bleaching disease in a chemically defended marine macroalga. Environ. Microbiol. 13, 529-537. doi: 10.1111/j.1462-2920.2010.02356.x

Charlson, R. J., Lovelock, J. E., Andreae, M. O., and Warren, S. G. (1987). Oceanic phytoplankton, atmospheric sulphur, cloud albedo and climate. Nature 326, 655-661. doi: 10.1038/326655a0

Choi, C. J., and Berges, J. A. (2013). New types of metacaspases in phytoplankton reveal diverse origins of cell death proteases. Cell Death Dis. 4, 1-7. doi: 10.1038 /cddis. 2013.21

Chow, J. S., Lee, C., and Engel, A. (2015). The influence of extracellular polysaccharides, growth rate, and free coccoliths on the coagulation efficiency of Emiliania huxleyi. Mar. Chem. 175, 5-17. doi: 10.1016/j.marchem.2015. 04.010

Coll, N. S., Epple, P., and Dangl, J. L. (2011). Programmed cell death in the plant immune system. Cell Death Differ. 18, 1247-1256. doi: 10.1038/cdd.2011.37

Daniels, C. J., Sheward, R. M., and Poulton, A. J. (2014). Biogeochemical implications of comparative growth rates of Emiliania huxleyi and Coccolithus species. Biogeosciences 11, 6915-6925. doi: 10.5194/bg-11-6915-2014

Douglas, A. E. (2003). Coral bleaching-how and why? Ma. Pollut. Bull. 46, 385-392. doi: 10.1016/S0025-326X(03)00037-7 
Egan, S., Harder, T., Burke, C., Steinberg, P., Kjelleberg, S., and Thomas, T. (2013). The seaweed holobiont: understanding seaweed-bacteria interactions. FEMS Microbiol. Rev. 37, 462-476. doi: 10.1111/1574-6976. 12011

Fernandes, N., Case, R. J., Longford, S. R., Seyedsayamdost, M. R., Steinberg, P. D., Kjelleberg, S., et al. (2011). Genomes and virulence factors of novel bacterial pathogens causing bleaching disease in the marine red alga Delisea pulchra. PLoS ONE 6:e27387. doi: 10.1371/journal.pone.0027387

Frada, M., Probert, I., Allen, M. J., Wilson, W. H., and de Vargas, C. (2008). The "Cheshire Cat" escape strategy of the coccolithophore Emiliania huxleyi in response to viral infection. Proc. Natl. Acad. Sci. U.S.A. 105, 15944-15949. doi: 10.1073/pnas.0807707105

Frada, M. J., Bidle, K. D., Probert, I., and de Vargas, C. (2012). In situ survey of life cycle phases of the coccolithophore Emiliania huxleyi (Haptophyta). Environ. Microbiol. 14, 1558-1569. doi: 10.1111/j.1462-2920.2012. 02745.x

Fulton, J. M., Fredricks, H. F., Bidle, K. D., Vardi, A., Kendrick, B. J., DiTullio, G. R., et al. (2014). Novel molecular determinants of viral susceptibility and resistance in the lipidome of Emiliania huxleyi. Environ. Microbiol. 16, 1137-1149. doi: $10.1111 / 1462-2920.12358$

Gao, K., Ruan, Z., Villafane, V. E., Gattuso, J., and Helbling, E. W. (2009). Ocean acidification exacerbates the effect of UV radiation on the calcifying phytoplankter Emiliania huxleyi. Limnol. Oceanogr. 54, 1855-1862. doi: 10.4319/lo.2009.54.6.1855

Gardiner, M., Thomas, T., and Egan, S. (2015). A glutathione peroxidase (GpoA) plays a role in the pathogenicity of Nautella italica strain R11 towards the red alga Delisea pulchra. FEMS Microbiol. Ecol. 91:fiv021. doi: 10.1093/femsec/fiv021

Gonzalez, J. M., Simo, R., Massana, R., Covert, J. S., Casamayor, E. O., Pedros-Alio, C., et al. (2000). Bacterial community structure associated with a dimethylsulfoniopropionate-producing North Atlantic algal bloom. Appl. Environ. Microbiol. 66, 4237-4246. doi: 10.1128/AEM.66.10.42374246.2000

Green, D. H., Echavarri-Bravo, V., Brennan, D., and Hart, M. C. (2015). Bacterial diversity associated with the coccolithophorid algae Emiliania huxleyi and Coccolithus pelagicus f. braarudii. Biomed. Res. Int. 2015, 1-15. doi: $10.1155 / 2015 / 194540$

Green, J. C., Course, P. A., and Tarran, G. A. (1996). The life-cycle of Emiliania huxleyi: a brief review and a study of ploidy levels analysed by flow cytometry. J. Mar. Syst. 9, 33-44. doi: 10.1016/0924-7963(96)00014-0

Guillard, R. R. L., and Hargraves, P. E. (1993). Stichochrysis immobilis is a diatom, not a chrysophyte. Phycologia 32, 234-236. doi: 10.2216/i0031-8884-32-3-234.1

Harvell, C. D., Mitchell, C. E., Ward, J. R., Altizer, S., Dobson, A. P., Ostfeld, R. S., et al. (2002). Climate warming and disease risks for terrestrial and marine biota. Science 296, 2158-2162. doi: 10.1126/science. 1063699

Helliwell, K. E., Wheeler, G. L., Leptos, K. C., Goldstein, R. E., and Smith, A. G. (2011). Insights into the evolution of vitamin B12 auxotrophy from sequenced algal genomes. Mol. Biol. Evol. 28, 1-13. doi: 10.1093/molbev/msr124

Huisman, J. (2000). Marine Plants of Australia. Nedlands, WA: University of Western Australia Press.

Jenkins, S. R., Hawkins, S. J., and Norton, T. A. (1999). Direct and indirect effects of a macroalgal canopy and limpet grazing in structuring a sheltered inter-tidal community. Mar. Ecol. Prog. Ser. 188, 81-92. doi: 10.3354/meps 188081

Kendrick, B. J., DiTullio, G. R., Cyronak, T. J., Fulton, J. M., Van Mooy, B. A., and Bidle, K. D. (2014). Temperature-induced viral resistance in Emiliania huxleyi (Prymnesiophyceae). PLoS ONE 9:e112134. doi: 10.1371/journal.pone.0112134

Kushmaro, A., Loya, Y., Fine, M., and Rosenberg, E. (1996). Bacterial infection and coral bleaching. Nature 380:396. doi: 10.1038/380396a0

Labeeuw, L., Khey, J., Bramucci, A. R., Atwal, H., de la Mata, P., Haryunk, J., et al. (2016). Indole-3-acetic acid is produced by Emiliania huxleyi cocolith-bearing cells and triggers a physiological response in bald cells. Front. Microbiol. 7:828. doi: $10.3389 /$ fmicb.2016.00828

Lam, E., Kato, N., and Lawton, M. (2001). Programmed cell death, mitochondria and the plant hypersensitive response. Nature 411, 848-853. doi: $10.1038 / 35081184$

Madeo, F., Herker, E., Maldener, C., Klissing, S., Lachelt, S., Herlan, M., et al. (2002). A caspase-related protease regulated apoptosis in yeast. Mol. Cell. 9, 911-917.
Oliver, E. C. J., Wotherspoon, S. J., Chamberlain, M. A., and Holbrook, N. J. (2014). Projected Tasman Sea extremes in sea surface temperature through the twenty-first century. J. Climate 27, 1980-1998. doi: 10.1175/JCLI-D-13-00259.1

Paasche, E. (2002). A review of the coccolithophorid Emiliania huxleyi (Prymnesiophyceae), with particular reference to growth, coccolith formation, and calcification-photosynthesis interactions. Phycologia 40, 503-529. doi: 10.2216/i0031-8884-40-6-503.1

Quinn, P. K., and Bates, T. S. (2011). The case against climate regulation via oceanic phytoplankton sulphur emissions. Nature 480, 51-56. doi: 10.1038/nature10580

Reisch, C. R., Moran, M. A., and Whitman, W. B. (2011). Bacterial catabolism of dimethylsulfoniopropionate (DMSP). Front. Microbiol. 2:172. doi: 10.3389/fmicb.2011.00172

Rhodes, L. L., Peake, B. M., MacKenzie, A. L., and Marwick, S. (1995). Coccolithophores Gephyrocapsa oceanica and Emiliania huxleyi (Prymnesiophyceae=Haptophyceae) in New Zealand's coastal waters: characteristics of blooms and growth in laboratory culture. N. Z. J. Mar. Freshw. Res. 29, 345-357. doi: 10.1080/00288330.1995.9516669

Rosenberg, E., Kushmaro, A., Kramarsky-Winter, E., Banin, E., and Yossi, L. (2009). The role of microorganisms in coral bleaching. ISME J. 3, 139-146. doi: 10.1038/ismej.2008.104

Sapp, M., Schwaderer, A. S., Wiltshire, K. H., Hoppe, H. G., Gerdts, G., and Wichels, A. (2007). Species-specific bacterial communities in the phycosphere of microalgae? Microb Ecol. 53, 1-17. doi: 10.1007/s00248-006-9162-5

Schmidt, S., Harlay, J., Borges, A. V., Groome, S., Delilled, B., Roevros, N., et al. (2013). Particle export during a bloom of Emiliania huxleyi in the North-West European continental margin. J. Mar. Syst. 109-110, 182-190. doi: 10.1016/j.jmarsys.2011.12.005

Schreiber, U. (1998). Chlorophyll fluorescence: new instruments for special applications. Photosynthesis Mech. Effects 5, 4253-4258.

Schreiber, U., Schliwa, U., and Bilger, W. (1986). Continuous recording of photochemical and non-photochemical chlorophyll fluorescence quenching with a new type of modulation fluorometer. Photosynthesis Res. 10, 51-62. doi: $10.1007 / \mathrm{BF} 00024185$

Seyedsayamdost, M. R., Case, R. J., Kolter, R., and Clardy, J. (2011). The Jekylland-Hyde chemistry of Phaeobacter gallaeciensis. Nat. Chem. 3, 331-335. doi: $10.1038 /$ nchem. 1002

Simó, R. (2004). From cells to globe: approaching the dynamics of DMS(P) in the ocean at multiple scales. Can. J. Fisheries Aquat. Sci. 61, 673-684. doi: 10.1139/f04-030

Smirnova, A., Li, H., Weingart, H., Aufhammer, S., Burse, A., Finis, K., et al. (2001). Thermoregulated expression of virulence factors in plant-associated bacteria. Arch. Microbiol. 176, 393-399. doi: 10.1007/s002030100344

Smith, T. M., Reynolds, R. W., Peterson, T. C., and Lawrimore, J. (2008). Improvements to NOAA's Historical Merged Land-Ocean Surface Temperature Analysis (1880-2006). J. Climate 21, 2283-2296. doi: 10.1175/2007JCLI2100.1

Sundström, J. F., Vaculova, A., Smertenko, A. P., Savenkov, E. I., Golovko, A., Minina, E., et al. (2009). Tudor staphylococcal nuclease is an evolutionarily conserved component of the programmed cell death degradome. Nat. Cell Biol. 11, 1347-1354. doi: 10.1038/ncb1979

Thrall, P. H., Burdon, J. J., and Young, A. (2001). Variation in resistance and virulence among demes of a plant host-pathogen metapopulation. J. Ecol. 86, 736-748. doi: 10.1111/j.1461-0248.2012.01749.x

van Kooten, O., and Snel, J. F. H. (1990). The use of chlorophyll fluorescence nomenclature in plant stress physiology. Photosynthesis Res. 25, 147-150. doi: 10.1007/BF00033156

Vardi, A., Van Mooy, B. A., Fredricks, H. F., Popendorf, K. J., Ossolinski, J. E., Haramaty, L., et al. (2009). Viral glycosphingolipids induce lytic infection and cell death in marine phytoplankton. Science 326, 861-865. doi: $10.1126 /$ science. 1177322

von Dassow P., John, U., Ogata, H., Probert, I., Bendif, M., Kegel, J. U., et al. (2015). Life-cycle modification in open oceans accounts for genome variability in a cosmopolitan phytoplankton. ISME J. 9, 1365-1377. doi: 10.1038/ismej.2014.221

von Dassow P., Ogata, H., Probert, I., Wincker, P., Da, Silva, C., Audic, S., et al. (2009). Transcriptome analysis of functional differentiation between haploid and diploid cells of Emiliania huxleyi, a globally significant photosynthetic calcifying cell. Genome Biol. 10, 1-33. doi: 10.1186/gb-2009-10-10-r114 
Voss, K. J., Balch, W. M., and Kilpatrick, K. A. (1998). Scattering and attenuation properties of Emiliania huxleyi cells and their detached coccoliths. Limnol. Oceanogr. 43, 870-876. doi: 10.4319/lo.1998.43.5.0870

Webb, A. L., Malin, G., Hopkins, F. E., Ho, K. L., Riebesell, U., Schulz, K. G., et al. (2016). Ocean acidification has different effects on the production of dimethylsulfide and dimethylsulfoniopropionate measured in cultures of Emiliania huxleyi and a mesocosm study: a comparison of laboratory monocultures and community interactions. Environ. Chem. 13, 314-329. doi: 10.1071/EN14268

Weinberger, F., Freidlander, M., and Gunkel, W. (1994). A bacterial facultative parasite of Gracilaria conferta. Dis. Aquat. Organ. 18, 135-141. doi: 10.3354/dao018135

Wilkinson, D., and Ramsdale, M. (2011). Proteases and caspase-like activity in the yeast Saccharomyces cerevisiae. Biochem. Soc. Trans. 39, 1502-1508. doi: 10.1042/BST0391502

Wilson, W. H., Tarran, G. A., Schroeder, D., Cox, M., Oke, J., and Malin, G. (2002). Isolation of viruses responsible for the demise of an Emiliania huxleyi bloom in the English Channel. J. Mar. Biol. Assoc. 82, 369-377. doi: 10.1017/S002531540200560X

Wilson, W. H., Van Etten, J. L., and Allen, M. J. (2009). The phycodnaviridae: the story of how tiny giants rule the world. Curr. Top. Microbiol. Immunol. 328, $1-42$.

Conflict of Interest Statement: The authors declare that the research was conducted in the absence of any commercial or financial relationships that could be construed as a potential conflict of interest.

Copyright (c) 2016 Mayers, Bramucci, Yakimovich and Case. This is an openaccess article distributed under the terms of the Creative Commons Attribution License (CC BY). The use, distribution or reproduction in other forums is permitted, provided the original author(s) or licensor are credited and that the original publication in this journal is cited, in accordance with accepted academic practice. No use, distribution or reproduction is permitted which does not comply with these terms. 